Business and Economics Research Journal

Volume 8 Number 12017

pp. $35-48$

ISSN: $1309-2448$

DOI Number: 10.20409/berj.2017126243

\title{
Stability of Money Demand Function in Turkey
}

\author{
Oğuz Tümtürk
}

\begin{abstract}
The purpose of this study is to investigate the money demand function and its stability in Turkey using annual data over the period of 1970 and 2013. Based on the three specifications of money demand function, cointegration and the dynamic regression estimation results reveal that more flexible version of money demand specification that links the log of real money balances, In M/P, to the log of real GDP, In $Y / P$, and the log of the nominal interest rate, Ini, performs better than the money demand specifications assuming unitary income elasticities. Moreover, based on the stability test on the flexible specification of money demand, the narrow monetary aggregate M1 is found to be stable.
\end{abstract}

Keywords: Money Demand, Income and Interest Elasticities, Stability, Dynamic OLS

JEL Classification: E41, E52

\section{Introduction}

Since the pioneering work by Friedman (1956), the money demand function has been subjected to great deal of attention by scholars, policymakers and governors. Stability of money demand function is crucial in macroeconomics since the proper design of the monetary policy depends upon the existence of the stable money demand function. As stated by Laidler (1982), "No proposition in macroeconomics has received more attention than that there exists, at the level of the aggregate economy, a stable demand for money function"(p. 39).

The conventional money demand function relates the real money balances with a nominal interest rate and a measure of real economic activity. Under the assumption of strong and stable relationship between the goal variable (say inflation) and targeted monetary aggregate, monetary authority can adjust the average growth rate of money that is consistent with price stability, given the average growth rate of the economy and nominal interest rate. However, if there is no strong and stable relationship between the goal variables and the targeted monetary aggregates, monetary targeting does not work as experienced by several countries including the United Kingdom, Canada and Switzerland. As stated by Mishkin (1998), the weak and unstable relationship will not produce the desired outcome on the goal variable, and targeted aggregate will no longer provides an adequate signal about the stance of monetary policy.

aRes. Assist., PhD., Ordu University, Unye Faculty of Economics and Administrative Sciences, Ordu, Turkiye, oguz.tumturk@gmail.com 
In international literature, the existence of stable money demand functions was widely accepted till end of 1980s, and monetary targeting had been used as a successful strategy for monetary policy in order to achieve price stability. However, some unsuccessful experiences of developed countries conducting monetary targeting policy suggested that the demand for money is not as stable as thought. In particular, increasing diversity in financial instruments, financial liberalization, regulatory changes that occurred in the banking sector and technological innovations associated with electronical payments required to reconsider stability of money demand after 1980s. These fundamental changes in financial markets has weakened the stable and strong relationship between targeted aggregate and goal variable in some countries such as the United States and the United Kingdom. Hence, the demand for money has been started to consider as "unstable" by the monetary authorities in these countries.

Turkey has not been independent from all these fundamental changes which occur in the financial markets. Turkish financial markets also experienced financial liberalization and deregulation during 1990s. A natural question then arises, "Has the money demand been stable over the last decades in Turkey?" Hence, the main purpose of this study is to investigate the stability of money demand function in Turkey using the annual data over the period of 1970 and 2013. For this purpose, this study first addresses the question of which functional form of money demand regression equations is valid for empirical work in Turkey by following the traditional approach (or Keynesian Liquidity Preference) which relates the money balances with nominal interest rates and national income. Estimation of the proper functional form is quite crucial since money demand elasticities and the stability of money demand might depend upon the accepted functional form. Thus, the main contribution of this article into the literature is to choose the best statistical form of Keynesian money demand among the competing specifications for Turkey. For this purpose, Johansen (1991) cointegration tests and Dynamic OLS are conducted in order to estimate the appropriate long run money demand specification. Then, based on the appropriate functional form of the money demand, the stability of money demand function in Turkey is tested. At this stage, the main purpose is to have an idea whether or not the fundamental changes in financial markets starting with 1990s have weakened the stability of money demand and changed the constancy of estimated coefficients.

The organization of the article is as follows. The following two sections provide a brief summary of the theoretical framework of the different specifications of money demands and an overview of the literature published on related studies. Section 4 discusses the data definitions and estimation method while section 5 presents empirical estimates regarding the appropriate money demand specification for Turkey and its stability. Finally, section 6 presents a brief summary and conclusion.

\section{Theoretical Framework}

In this study, three competing specifications of money demand are analyzed. First specification is proposed by Meltzer (1963), and it relates the natural logarithm of $m$, the ratio of money balances to nominal income, to the natural logarithm of nominal interest rates, i, via

$$
\mathrm{m}=\mathrm{Ai}{ }^{\gamma} \text { and } \ln \mathrm{m}=\ln \mathrm{A}+\gamma \ln \mathrm{i}
$$

where $A>0$ is a constant and $\gamma>0$ measures the interest rate elasticity of money demand. This specification is also called log-log specification of money demand. The rival specification is adapted from Cagan (1956), and links the natural logarithm of $m$ to the level of $i$ via

$$
\mathrm{m}=\mathrm{B} e^{\mu i} \quad \text { and } \quad \operatorname{lnm}=\ln \mathrm{B}+\mu \mathrm{i}
$$

where $B>0$ is a constant and $\mu>0$ measures the interest rate semi-elasticity of money demand. This specification is also called semi-log specification of money demand. Note that both specifications of money demand (1) and (2) impose a unitary income elasticity. Hence, the more flexible version of money demand specification that links the log of real money balances, In M/P, to the log of real GDP, In Y/P, and the log of the nominal interest rate, Ini, via 
$\ln \mathrm{M} / \mathrm{P}=\alpha+\beta_{\mathrm{y}} \ln \mathrm{Y} / \mathrm{P}+\beta_{\mathrm{i}} \operatorname{lni}$

will be considered, as well. The last equation is called flexible specification of money demand since it relaxes the assumption of unitary income elasticity. Theoretically, the sign of the income elasticity of money demand is expected to be positive while interest rate elasticity is expected to be negative.

\section{Literature Review}

Existence of stable and predictable money demand function has been subjected to extensive theoretical and empirical research in the both international and national literature.

Lucas (1988) tests the stability of the United States M1 money demand estimated by Meltzer (1963) by using data up to 1985 . He shows that there is a theoretical equilibrium relationship between real money, a nominal interest rate as a measure of the opportunity cost of money, and gross domestic product (GDP) as a measure of transactions. He also concludes that there is a stable relationship between those variables with a unitary income elasticity. Similarly, Hoffman and Rasche (1991) conclude that there exists strong evidence in support of a stable equilibrium demand functions for M1 real balances in the post-world War II United States economy.

However, as stated by Lucas and Nicolini (2015), long standing empirical relations connecting monetary aggregates to movements in prices and interest rates began to deteriorate in the 1980s and have not been restored since. Lucas and Nicolini claim that regulatory changes that occurred in the banking sector in the early 1980s in the United States can explain the apparent instability of money demand starting in the same period. They evaluate the effects of the regulatory changes and treat currency and different deposit types as alternative means of payments. They show that the new monetary aggregate performs remarkably well for all the period 1915-2012. Similarly, Telles and Zhou (2005) propose a different measure of money which includes the developments in sweep technology and changes in regulations at banking sector. They show that changing the monetary aggregate measure from 1980 onward preserves the long-run relationship between real money, the opportunity cost of money, and economic activity.

Hoffman, Rasche, and Tieslau (1995) provide strong evidence for the stability of long-run M1 demand functions in five industrial countries (United States, Japan, Canada, United Kingdom, and West Germany) using post-war quarterly data. Bahmani-Oskooee and Chomsisengphet (2002) test the stability of M2 money demand in 11 OECD countries, and they conclude that the stability tests reveal some sign of instability in the cases of Switzerland and the United Kingdom. Demand for money turns out to stable in the remaining nine cases (United States, Sweden, Norway, Japan, Italy, France, Canada, Austria, and Australia).

Bahmani-Oskooee and Rehman (2005) investigate the M1 and M2 money demand functions in seven Asian countries (India, Indonesia, Malaysia, Pakistan, the Philippines, Singapore and Thailand). The M1 monetary aggregate is stable over time in India, Indonesia and Singapore while in the remaining countries, the M2 aggregate is stable. Jusoh and Tahir (2009) state that M1 has stable relationship with income and interest rates for the case of China; however, M2 has not. Baharumshah, Mohd, and Masih (2009) examine the demand for broad money (M2) in China using the autoregressive distributed lag (ARDL) cointegration framework. The results confirm a stable, long-run relationship between $M 2$ and its determinants: real income, inflation, foreign interest rates and stock prices. Akinlo (2006) investigates the cointegrating property and stability of M2 money demand for Nigeria over the period 1970:1-2002:4. The results show that $\mathrm{M} 2$ is cointegrated with income, interest rate and exchange rate, and money demand function is stable. Nchor and Adamec (2016) test the demand for M1 and M2 monetary aggregates in Ghana, and find that the money demand function is stable over the period 1990-2014.

Volker and Jeong-Ryeol (2000) investigate the aggregate demand for money in Europe over the period 1980:Q1-1996:Q4, and they find that European money demand functions for M1 as well as for M3 is stable. Hayo (1999) tests the stability of money demand for narrow and broad money for the 11 European Union countries based on a quarterly data, and concludes that money demand models are stable. Jung (2016) 
estimates a portfolio demand approach for broad money M3 in the euro area covering the period 1999 to 2013. He finds that the main components of euro area M3 are largely stable and can be explained by fundamental factors such as a transaction variable and opportunity costs.

There are large number of studies investigating the stability of money demand for the case of Turkey, and the empirical evidences are mixed. Korap and Saatcioglu (2005) examine the Turkish broad money demand M2Y with quarterly data over the period 1987-2004. They use cointegration analysis and error correction mechanism, and find out that the broad money demand is insensitive to real income. Also, money demand function indicates some instabilities within estimation period. Altintas (2008) tests the stability of M2 money demand and its determinants (real income, interest rate and exchange rate) in Turkey using quarterly data over the period 1985:Q4-2006:Q4. The bounds test approach is combined with CUSUMSQ tests, and he indicates that M2 money demand is in a stable relationship with its determinants. Algan and Gencer (2011) test the determinants and stability of money demand in Turkey by using Multivariate Cointegration Analysis for the period between 1987:Q1 and 2007:Q2. Money demand functions are being estimated by creating alternative models with narrow and wide monetary aggregates, income, interest rate, inflation and exchange rate. They indicate that money demand function with narrow monetary aggregate $M 1$, is in a stable relationship with income and interest rate.

Gencer and Arisoy (2013) estimate the long run money demand (M2Y) for Turkish economy by testing the empirical relationship among real money, real income, interest rate, inflation and exchange rate over the period 1989:Q1-2010:Q4. ARDL bounds test results indicate that there is a long-run relationship between real money, real income, the exchange rate, inflation and interest rate. Time-varying parameters model estimation results reveal that both real income and exchange rate have positive effect on real money demand, whereas inflation and interest rate have a negative effect on real money demand. Dogru (2014) uses cointegration bound test-ARDL and Vector Error-Correction Model approaches to test money demand function of Mundel (1963), including exchange rate, for Turkey covering the period between 1970 and 2010. He finds out that $\mathrm{M} 2$ has long term stability, and $\mathrm{M} 2$ is cointegrated with income, interest rate and exchange rate. Also, money demand function has a significant and negative relationship with deposit interest rates in short-term.

Ozcan and Arı (2013) test the stability of M2 money demand using monthly data for the period 2005:12-2012:10. The results are in support of a long-run relationship among M2 monetary aggregate, real income, interest rate, and exchange rate. However, stability of money demand function is rejected. Thus, they conclude that it is not efficient for Central Bank of the Republic of Turkey (CBRT) to apply a monetary policy based on M2 monetary aggregate. Yılancı (2012) investigates the stability of the M2 money demand function in Turkey from 1989:Q1 to 2011:Q2 by employing bounds test and also rolling bounds test approaches. The results show that the money demand function is instable in the analysis period; thus the CBRT should not use the M2 broad money supply as a monetary policy instrument. Similarly, Atgür and Altay (2015) examine the relationship between the money demand and determinants of the money demand during the inflation targeting in Turkey for the period 2002:Q1-2013:Q2. ARDL Model and CUSUM test results reveal that there is not a stable relationship among income level, interest rate, inflation and $M 2$ money demand for both short run and long-run in Turkey. Ozdemir and Saygılı (2013) state that M2Y money balances, income and interest spread are not cointegrated when the VAR system is missing a measure of economic uncertainty. However, they find stable long run relations and coefficients when the correct measures of uncertainty are introduced to the system.

Before closing this section, it is worth mentioning the discussions in literature regarding the Divisia approach to monetary aggregation ${ }^{1}$ instead of simple sums in which all monetary components are assigned with a unitary weight such as M1, M2, M2Y, etc. For the case of the United States, Darrat, Chopin, and Lobo (2005) conclude that Divisia monetary aggregates are cointegrated with real GDP and interest rate. Moreover, they find that Divisia monetary aggregates have a stable long-run relationship with macroeconomic variables in both full and post-1980 sample period. Leong, Puah, Shazali, and Lau (2010) conclude that the Divisia M2 money demand in Malaysia is more stable over time and has the capability to produce more credible money demand function. Celik and Uzun (2009) perform the advanced panel 
cointegration tests over the period 1980:1-1993:3 for the United States, United Kingdom, Euro Area and Japan, and find the long run link between the Divisia monetary aggregates and income and interest rates in simple Keynesian money demand function. Celik (1999) derives the Divisia aggregates for Turkey for the period 1986:1-1999:2 in monthly frequency, and uses them to estimate the money demand function. The results demonstrate that Divisia $\mathrm{M} 1$ as the most promising aggregate to use in money demand studies based on the income and interest elasticities, and stability tests in Turkey.

\section{Data and Estimation Method}

The data consist of $\mathrm{T}=44$ annual observations extending from 1970 to 2013 for Turkey, and the time range has been widened as much as the data allow ${ }^{2}$. The monetary variable used in this study is M1, and M1 monetary aggregate data were obtained from Federal Reserve Economic Data (FRED). Nominal income is measured by quarterly nominal GDP, and it was obtained from Organization for Economic Co-operation and Development (OECD). The interest rate data were obtained from "Statistical Indicators 1923-2013" published by Turkish Statistical Institute-TUIK (2014). GDP Deflator (1987=100) data were also obtained from "Statistical Indicators 1923-2013" and used to convert both series for money M1 and GDP from nominal to real.

The estimation methodology applied in this study is Dynamic OLS. Dynamic regressions were employed in order to capture the arguments of Equations (1), (2), and (3). Stock and Watson (1993) showed that the dynamic regression estimates are asymptotically efficient under the assumption of cointegration. In addition, Dynamic DOLS method is a robust single equation approach which corrects for regressor endogeneity by adding lags and leads of first differences of the regressors, and it is specified as follows:

$$
Y_{t}=\beta_{0}+\beta X_{t}+\sum_{j=-p}^{p} d_{j} \Delta X_{t-j}+e_{t}
$$

\section{$\mathrm{Y}_{\mathrm{t}}$ : dependent variable}

$\mathrm{X}_{\mathrm{t}}$ : matrix of explanatory variables

$p=$ number of leads and lags

Therefore, the dynamic regressions for each specification will be estimated based on the general specification (4). These dynamic regressions are:

$$
\begin{aligned}
& \operatorname{lnm}=\ln \mathrm{A}+\gamma \operatorname{lni}+\sum_{j=-p}^{p} b_{j} \Delta \ln i_{t-j}+\mathrm{u}_{1 t} \\
& \operatorname{lnm}=\ln \mathrm{B}+\mu \mathrm{i}+\sum_{j=-p}^{p} c_{j} \Delta i_{t-j}+\mathrm{u}_{2 t} \\
& \ln \mathrm{M} / \mathrm{P}=\alpha+\beta_{\mathrm{y}} \ln \mathrm{Y} / \mathrm{P}+\beta_{i} \ln \mathrm{i}+\sum_{j=-p}^{p} h_{j} \Delta \ln Y / P_{t-j}+\sum_{j=-p}^{p} k_{j} \Delta \ln i_{t-j}+\mathrm{u}_{3 t}
\end{aligned}
$$

Johansen (1991) cointegration methodology is employed to test the cointegration relation for the variables in each specification (1), (2), and (3), being based on the maximum-likelihood estimation technique. Any VAR (Vector Autoregression) with $p$ lags can be written as

$$
\Delta Z_{t}=\mathrm{v}+\Pi Z_{t-1}+\sum_{i=1}^{m-1} \Gamma_{\mathrm{i}} \Delta Z_{t-i}+\varepsilon_{\mathrm{t}}
$$

where $Z_{t}$ is a $N x 1$ vector of variables, $v$ is a $N x 1$ vector of parameters, $\varepsilon_{t}$ is a $N \times 1$ vector of disturbances such that $\varepsilon_{t}$ is iid $(0, \Sigma)$, and $\Pi$ has a rank $0 \leq r \leq N$. Suppose that the vector $Z_{t-1}$ contains integrated of order one, $I(1)$, variables. Everything except the vector $\Pi \mathrm{Z}_{\mathrm{t}-1}$ in $(8)$ is integrated of order zero, $\mathrm{I}(0)$. This implies that the vector $\Pi Z_{t-1}$ must also be $I(0)$. This is only possible that multiplying the vector $Z_{t-1}$ by $\Pi$ produces the linear combinations of $\mathrm{Z}_{\mathrm{t}-1}$ that are $\mathrm{I}(0)$. When $\Pi$ has reduced rank $0<r<\mathrm{N}$ then it can be expressed as $\Pi=\theta \beta^{\top}$, and both $\theta$ and $\beta$ are Nxr matrices. $\beta$ is a matrix containing the cointegration vectors.

The first step in the Johansen methodology is to pretest each variable to determine its order of integration. Augmented Dickey-Fuller (ADF) (1979) test is performed on each series to determine their order 
of integration. Dickey and Fuller (1979) developed a procedure for testing whether a variable $y_{t}$ has a unit root or not, and they fit a model of the form

$$
\Delta y_{t}=\Phi+\psi y_{t-1}+\omega t+\sum_{j=1}^{k} \gamma_{j} \Delta y_{t-j}+\rho_{t}
$$

where $k$ is the number of lags used in the model, and $t$ is time trend. ADF test involves estimating regression (9) for each series and tests the null hypothesis of a unit root, $\mathrm{H}_{0}: \psi=0$ versus the alternative of a stationary process. In addition to the ADF test, the possible effects of structural breaks on the series are also taken into account by using Zivot and Andrews (1992) unit root test. Zivot and Andrews test is based on the principle of endogenous determination of single structural break. The break date is selected where the t-statistic from the ADF test of unit root is at minimum. The endogenous determination of break year makes Zivot and Andrews test more superior to other tests which exogenously determine the break years.

Based on the estimation results, the CUSUMSQ (cumulative sum of squares) test is conducted in order to investigate the stability of the appropriate money demand specification. In general, if the CUSUMSO move outside the critical line of the $5 \%$ significance level, the null hypothesis is rejected, meaning that the demand equation is stable over the period of study.

\section{Empirical Estimates}

As is standard in time series analysis, the statistical properties of the variables are examined using ADF unit root tests. The null hypothesis is that the variable contains a unit root, and the alternative is that the variable is generated by a stationary process. ADF unit root test results depend on the which version of test is used: trend and constant, constant, and none.

Table 1 displays ADF unit root test results. The optimal lag length is determined by using the Akaike (1973) Information Criterion (AIC). According to the ADF unit root test results, all variables in the equations (1), (2), and (3) are integrated of order one, I(1)

Table 1. ADF Unit Root Test Results

\begin{tabular}{|c|c|c|c|c|c|c|}
\hline & & \multicolumn{2}{|r|}{ Level } & \multicolumn{3}{|c|}{ First Differences } \\
\hline & & $\begin{array}{l}\text { Lags } \\
\text { (AIC) }\end{array}$ & $\begin{array}{c}\text { ADF T-Stat } \\
\text { [5\% Critical Value] }\end{array}$ & $\begin{array}{l}\text { Lags } \\
\text { (AIC) }\end{array}$ & $\begin{array}{c}\text { ADF T-Stat } \\
{[5 \% \text { Critical Value }]}\end{array}$ & Result \\
\hline \multirow{3}{*}{ Inm } & Trend and Constant & 1 & $-0.754[-3.532]$ & 0 & $-6.233[-3.532]$ & $\mathrm{I}(1)$ \\
\hline & Constant & 1 & $-1.417[-2.952]$ & 0 & $-6.065[-2.952]$ & $\mathrm{I}(1)$ \\
\hline & None & 1 & $0.002[-1.950]$ & 0 & $-6.126[-1.950]$ & $\mathrm{I}(1)$ \\
\hline \multirow{3}{*}{ Ini } & Trend and Constant & 1 & $-0.870[-3.532]$ & 0 & $-6.226[-4.224]$ & $\mathrm{I}(1)$ \\
\hline & Constant & 1 & $-1.442[-2.952]$ & 0 & $-5.666[-2.952]$ & $\mathrm{I}(1)$ \\
\hline & None & 1 & $-0.101[-1.950]$ & 0 & $-5.728[-1.950]$ & $\mathrm{I}(1)$ \\
\hline \multirow{3}{*}{$\mathbf{i}$} & Trend and Constant & 1 & $-1.105[-3.532]$ & 0 & $-7.099[-3.532]$ & I(1) \\
\hline & Constant & 1 & $-1.378[-2.952]$ & 0 & $-6.865[-2.952]$ & $\mathrm{I}(1)$ \\
\hline & None & 1 & $-0.705[-1.950]$ & 0 & $-6.949[-1.950]$ & $\mathrm{I}(1)$ \\
\hline \multirow{3}{*}{$\ln \mathrm{Y} / \mathrm{P}$} & Trend and Constant & 3 & $-1.643[-3.540]$ & 0 & $-5.900[-3.532]$ & $\mathrm{I}(1)$ \\
\hline & Constant & 3 & $-1.312[-2.958]$ & 0 & $-5.531[-2.952]$ & $\mathrm{I}(1)$ \\
\hline & None & 3 & $-1.451[-1.950]$ & 0 & $-5.206[-1.950]$ & $\mathrm{I}(1)$ \\
\hline \multirow{3}{*}{$\ln M / P$} & Trend and Constant & 3 & $0.542[-3.540]$ & 0 & $-5.900[-3.532]$ & $\mathrm{I}(1)$ \\
\hline & Constant & 3 & $1.364[-2.958]$ & 0 & $-5.531[-2.952]$ & $\mathrm{I}(1)$ \\
\hline & None & 3 & $1.411[-1.950]$ & 0 & $-5.206[-1.950]$ & $\mathrm{I}(1)$ \\
\hline
\end{tabular}


So far, the possible effects of any structural breaks on the series were not taken into account. However, the stationarity of the any time series might be sensitive to the structural breaks. To put it more clearly, if the effects of possible structural breaks in the time series are overlooked, ADF tests might be biased towards having unit root. This leads to make wrong judgement with regarding order of integration. Since Turkey had several recessions which might cause some structural breaks on the series during the sample period, Zivot and Andrews (1992) test is also employed ${ }^{4}$. Table 2 shows the results when one endogenous break is considered. Similar to ADF test, Zivot and Andrews test results suggest that null hypothesis of unit root cannot be rejected for all variables when single break is included.

Table 2. Zivot and Andrews Test

\begin{tabular}{|c|c|c|c|c|}
\hline Variable & Model & $\begin{array}{c}\text { Minimum T- Statistic (Lag } \\
\text { Length }\end{array}$ & $\begin{array}{c}\text { Critical Values at 5\% } \\
\text { Significance Level }\end{array}$ & Break Year \\
\hline \multirow{4}{*}{ Inm } & Trend & $-4.083(0)$ & -4.42 & 1998 \\
\cline { 2 - 5 } & Intercept & $-3.252(0)$ & -4.80 & 2003 \\
\cline { 2 - 5 } & Both & $-4.007(0)$ & -5.08 & 1994 \\
\hline \multirow{4}{*}{ Ini } & Trend & $-3.500(0)$ & -4.42 & 1992 \\
\cline { 2 - 5 } & Intercept & $-3.007(0)$ & -4.80 & 1979 \\
\cline { 2 - 5 } & Both & $-3.402(0)$ & -5.08 & 1991 \\
\hline \multirow{4}{*}{$\mathbf{i}$} & Trend & $-3.706(2)$ & -4.42 & 1995 \\
\cline { 2 - 5 } & Intercept & $-4.026(2)$ & -4.80 & 1999 \\
\cline { 2 - 5 } & Both & $-4.472(2)$ & -5.08 & 1999 \\
\hline \multirow{3}{*}{ In Y/P } & Trend & $-3.970(0)$ & -4.42 & 1986 \\
\cline { 2 - 5 } & Intercept & $-4.402(0)$ & -4.80 & 1980 \\
\cline { 2 - 5 } & Both & $-4.360(0)$ & -5.08 & 1980 \\
\hline \multirow{3}{*}{ In M/P } & Trend & $-4.504(2)$ & -4.93 & 1997 \\
\cline { 2 - 5 } & Intercept & $-1.425(2)$ & -4.80 & \\
\cline { 2 - 5 } & Both & $-3.959(2)$ & -5.08 & \\
\hline
\end{tabular}

Note: The null hypotheses stating that the first differences of all variables contain unit roots are rejected at $5 \%$ significance level. a) Lag length is selected via TTest

Since all variables are I(1) (with and without structural breaks), Johansen (1991) methodology ${ }^{5}$ is employed in order to test the cointegration relation for the variables in each specification of money demand (1), (2), and (3). To test for cointegration, the number of lags included in the VAR must be specified. For this purpose, one lag is included in the VAR for both equations (1) and (2), and three lags are included in the VAR for the equation (3) based on the Akaike Information Criterion. Also, it is allowed the level data to have trends. Johansen's testing procedure starts with the test for zero cointegration $(\operatorname{rank}(r)=0)$ equations and then accepts the first null hypothesis that is not rejected. If the null hypothesis of zero cointegration vectors can be rejected, then the corresponding equation ( 1 or 2 or 3 ) represents a cointegrating relationship. The Johansen's cointegration test results have been reported in Tables 3, 4, and 5.

In Tables 3, 4, and 5, trace tests under the log-log and flexible specifications of money demand indicate one cointegration equation $(r=1)$ while it indicates zero cointegration equations under the semi-log specification at the $5 \%$ significance level. These results provide statistical evidence in favor of money demand relationship of the equation (1) and (3). Since the variables $\mathrm{Inm}$ and $\mathrm{i}$ are not cointegrated, the estimation of the semi-log specification of money demand provides spurious results. 
Table 3. Determination of Rank for Log-log Specification

\begin{tabular}{|c|c|c|c|}
\hline $\begin{array}{c}\text { Null } \\
\text { Hypothesis }\end{array}$ & $\begin{array}{c}\text { Alternative } \\
\text { Hypothesis }\end{array}$ & $\begin{array}{c}\text { Trace } \\
\text { Statistics }\end{array}$ & $\begin{array}{c}\mathbf{5 \%} \text { critical } \\
\text { value }\end{array}$ \\
\hline$r=0$ & $r=1$ & 23.08 & 18.17 \\
\hline$r=1$ & $r=2$ & 3.14 & 3.80 \\
\hline
\end{tabular}

Table 4. Determination of Rank for Semi-log Specification

\begin{tabular}{|c|c|c|c|}
\hline $\begin{array}{c}\text { Null } \\
\text { Hypothesis }\end{array}$ & $\begin{array}{c}\text { Alternative } \\
\text { Hypothesis }\end{array}$ & $\begin{array}{c}\text { Trace } \\
\text { Statistics }\end{array}$ & $\begin{array}{c}\mathbf{5 \%} \text { critical } \\
\text { value }\end{array}$ \\
\hline$r=0$ & $r=1$ & 14.97 & 18.2 \\
\hline$r=1$ & $r=2$ & 1.98 & 3.74 \\
\hline
\end{tabular}

Table 5. Determination of Rank for Flexible Specification

\begin{tabular}{|c|c|c|c|}
\hline $\begin{array}{c}\text { Null } \\
\text { Hypothesis }\end{array}$ & $\begin{array}{c}\text { Alternative } \\
\text { Hypothesis }\end{array}$ & $\begin{array}{c}\text { Trace } \\
\text { Statistics }\end{array}$ & $\begin{array}{c}\mathbf{5 \%} \text { critical } \\
\text { value }\end{array}$ \\
\hline$r=0$ & $r=1$ & 40.61 & 34.55 \\
\hline$r=1$ & $r=2$ & 16.05 & 18.17 \\
\hline
\end{tabular}

Now, dynamic OLS regressions (5) and (7) is estimated. Ireland (2009) states in his paper that adding leads and lags of $\Delta \mathrm{lni}$ and $\Delta \mathrm{ln} \mathrm{Y} / \mathrm{P}$ to the estimated equations controls for possible correlation between the " $\Delta \mathrm{Ini}$ or $\Delta \mathrm{In} \mathrm{Y} / \mathrm{P}$ " and the "residual" from the cointegrating relationship linking

a) Inm and Ini for equation (1)

b) In $\mathrm{M} / \mathrm{P}$, Ini, and In Y/P for equation (3)

however, any serial correlation that remains in the error term from the dynamic equation must still be accounted for when constructing standard errors for the dynamic OLS estimates. Hence, heteroskedasticity and autocorrelation consistent standard errors (or Newey-West standard errors), developed by Newey and West (1987), are used to adjust the covariance matrix of the parameters to produce consistent estimates when there is autocorrelation in addition to possible heteroskedasticity. The Newey-West standard errors are calculated conditionally on a choice of lag truncation parameter, $\mathrm{q}$. Therefore, dynamic OLS estimates will be given by using $\mathrm{p}$ leads and lags of $\Delta \operatorname{lni}$ or $\Delta \mathrm{ln} \mathrm{Y} / \mathrm{P}$ and various values of the lag truncation parameter q.

Table 6 displays the estimates of the intercept and slope coefficients obtained from the dynamic OLS regression of long run relationship for the equation (1) with $\mathrm{p}$ leads and lags on $\Delta \mathrm{Ini}$. Also, the Newey-West heteroskedasticity and autocorrelation consistent standard errors are produced on a choice of various values of q regression-error autocorrelations. According to the results in Table 6, interest rate elasticities of money demand are around -0.62 and -0.63 , and negative signs are consistent with economic theory, as expected. Moreover, standard errors of $\gamma_{\mathrm{e}}\left(\mathrm{s} . \mathrm{e} .\left(\gamma_{\mathrm{e}}\right)\right)$ show that the estimates of the interest rate elasticities are significantly different from zero. On the other hand, Table 7 displays the results of the flexible specification of money demand. 
Table 6. Dynamic OLS Estimates, Log-log Specification

\begin{tabular}{|c|c|c|c|c|}
\hline & $\eta_{e}$ & $V_{e}$ & s.e. $\left(v_{e}\right)$ & $(p, q)$ \\
\hline \multirow{9}{*}{$\ln m=\eta+\gamma \ln i$} & -0.636 & -0.625 & $0.055^{*}$ & $p=1, q=2$ \\
\hline & & & $0.057^{*}$ & $p=1, q=4$ \\
\hline & & & $0.058^{*}$ & $p=1, q=6$ \\
\hline & -0.627 & -0.629 & $0.063^{*}$ & $p=2, q=2$ \\
\hline & & & 0.059* & $p=2, q=4$ \\
\hline & & & $0.056^{*}$ & $p=2, q=6$ \\
\hline & -0.635 & -0.628 & $0.082^{*}$ & $p=3, q=2$ \\
\hline & & & $0.080 *$ & $p=3, q=4$ \\
\hline & & & $0.076 *$ & $p=3, q=6$ \\
\hline
\end{tabular}

Notes: The table reports $\eta_{e}$ and $\gamma_{e}$, the estimates of the intercept and slope coefficients obtained from a dynamic OLS regression (5) linking Inm and Ini with $\mathrm{p}$ leads and lags on $\Delta$ Ini. Also, the Newey-West standard errors are calculated on a choice of various values of the lag truncation parameter $q$. * indicates that slope coefficients are statistically significant at $5 \%$ significance level.

Similar to Table 6, Table 7 shows the estimates of the intercept and slope coefficients obtained from dynamic OLS regression of long run relationship for the equation (3) with $\mathrm{p}$ leads and lags on $\Delta \ln i$ and $\Delta \mathrm{ln}$ $\mathrm{Y} / \mathrm{P}$. Also, the Newey-West heteroskedasticity and autocorrelation consistent standard errors are produced on a choice of various values of q regression-error autocorrelations. Table 7 reveals that interest rate elasticities of money demand are estimated between -0.50 and -0.54 . The income elasticities of money demand are estimated between 0.65 and 0.76 based on the p chosen. Moreover, the negative sign of the interest rate elasticities, and the positive sign of the income elasticities adhere to economic theory. Standard errors of $\beta_{y} e_{y}\left(\operatorname{s.e}\left(\beta_{y} e_{y}\right)\right.$ and $\beta_{i}{ }_{i}\left(s . e .\left(\beta_{i}{ }_{i}\right)\right)$ reveal that the estimates of the income and interest rate elasticities from the dynamic regressions are significantly different from zero. The point estimates of the income elasticities in Table 7 are quite lower than 1, and all of the Wald tests based on different $p$ and $q$ reject the null hypothesis of a unitary income elasticities. The last result suggests that flexible specification provides the best description of the money demand in comparison to the log-log specification assuming unitary income elasticity.

Table 7. Dynamic OLS Estimates, Flexible Specification

\begin{tabular}{|c|c|c|c|c|c|c|c|}
\hline \multirow{10}{*}{$\begin{array}{c}\text { In M/P } \\
= \\
\alpha \\
+ \\
\beta_{y} \ln Y / P \\
+ \\
\beta_{i} \operatorname{lni}\end{array}$} & $\alpha^{e}$ & $\boldsymbol{\beta}_{\mathrm{y}}^{\mathrm{e}}$ & s.e $\left(\beta_{y}^{e}\right)$ & $\overline{\beta_{i}}$ & s.e. $\left(\beta_{i}{ }_{i}\right)$ & $(p, q)$ & $\begin{array}{c}\text { Wald }\left(\beta^{e}{ }_{y}=1\right) \\
\text { Prob }>F\end{array}$ \\
\hline & 3.95 & 0.654 & $0.055^{*}$ & -0.500 & $0.039 *$ & $p=1, q=2$ & 0.000 \\
\hline & & & $0.060 *$ & & $0.042 *$ & $p=1, q=4$ & 0.000 \\
\hline & & & $0.061 *$ & & $0.042 *$ & $p=1, q=6$ & 0.000 \\
\hline & 3.02 & 0.723 & 0.058* & -0.524 & $0.044^{*}$ & $p=2, q=2$ & 0.000 \\
\hline & & & $0.062 *$ & & $0.043 *$ & $p=2, q=4$ & 0.000 \\
\hline & & & 0.063* & & $0.044^{*}$ & $p=2, q=6$ & 0.00 \\
\hline & 2.48 & 0.761 & $0.084^{*}$ & -0.542 & $0.043^{*}$ & $p=3, q=2$ & 0.011 \\
\hline & & & $0.084 *$ & & $0.037^{*}$ & $p=3, q=4$ & 0.012 \\
\hline & & & 0.086* & & $0.033^{*}$ & $p=3, q=6$ & 0.013 \\
\hline
\end{tabular}

Notes: The table reports $\alpha^{e}, \beta_{y}{ }_{y}$, and $\beta_{i}{ }_{i}$, the estimates of the intercept and slope coefficients obtained from a dynamic OLS regression (7) linking In M/P, In Y/P and Ini with $\mathrm{p}$ leads and lags on $\Delta$ Ini and $\Delta \ln \mathrm{Y} / \mathrm{P}$. Also, the Newey-West standard errors are calculated on a choice of various values of the lag truncation parameter $q . *$ indicates that slope coefficients are statistically significant at $5 \%$ significance level. Wald (F) statistic is used to test the null hypothesis of a unitary long run income elasticity, $\beta^{\mathrm{e}}{ }_{\mathrm{y}}=1$. 


\subsection{Stability of Money Demand Function}

CUSUMSQ test, proposed by Brown, Durbin, and Evans (1975), is conducted in order to investigate the stability of coefficients in a multiple linear regression model. Under the null hypothesis of coefficient constancy, values of the sequence outside an expected bounds suggest structural change in the model over time of the estimation period.

Oskooee (2002) states in his study that cointegration does not necessarily mean the estimated parameters are stable over time. Hence, by following Oskoee, the CUSUMSQ test is also employed in order to test the constancy of the coefficients estimated from the dynamic regressions in Table 7. According to the CUSUMSQ test, if the plot of cumulative sum of squares of recursive residuals stays within $5 \%$ significance level (reflected by two straight lines), then coefficients estimates are said to be stable. Figures 1,2 , and 3 reveal that the plots of statistics remain between the critical bounds for each $p=1,2,3$. This result suggests that the financial developments and liberalization in Turkish economy starting with 1990s have not changed the stability of M1 money demand, and estimated coefficients have remained stable over time.

Figure 1. Plot of Cumulative Sum of Squares of Recursive Residuals, $p=1$

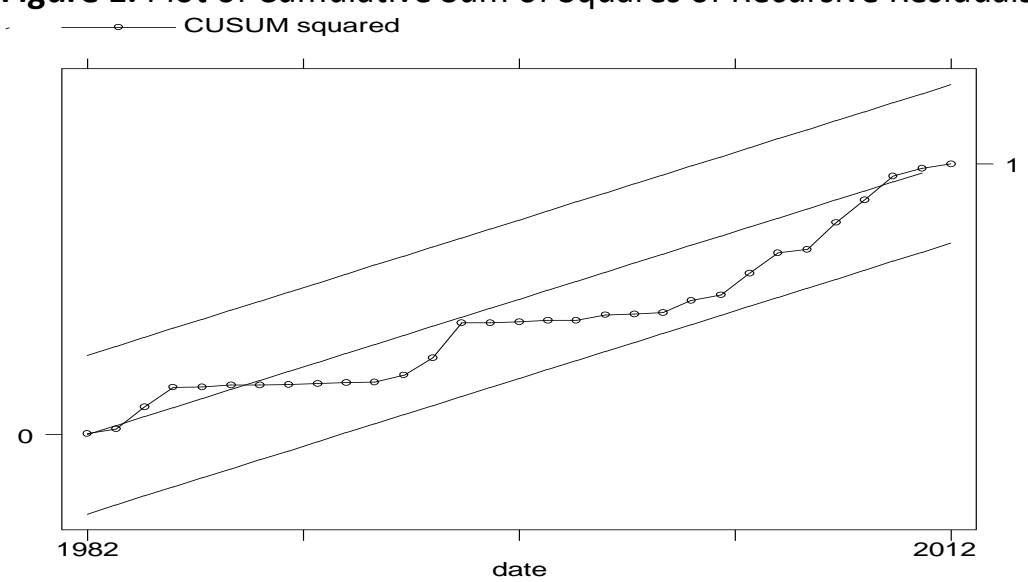

Figure 2. Plot of Cumulative Sum of Squares of Recursive Residuals, $p=2$

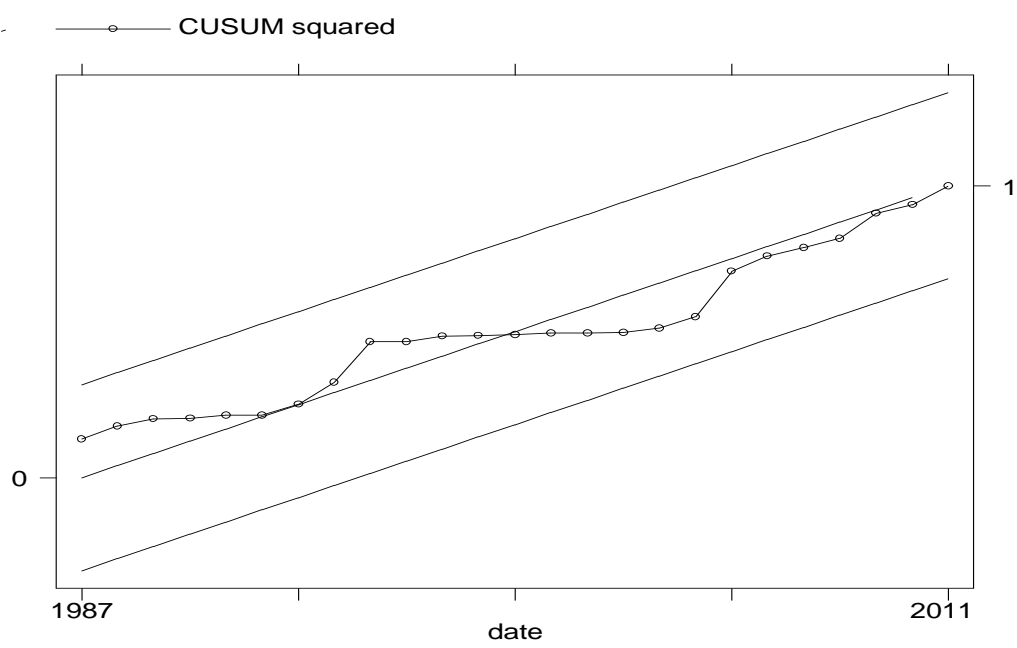


Figure 3. Plot of Cumulative Sum of Squares of Recursive Residuals, $p=3$

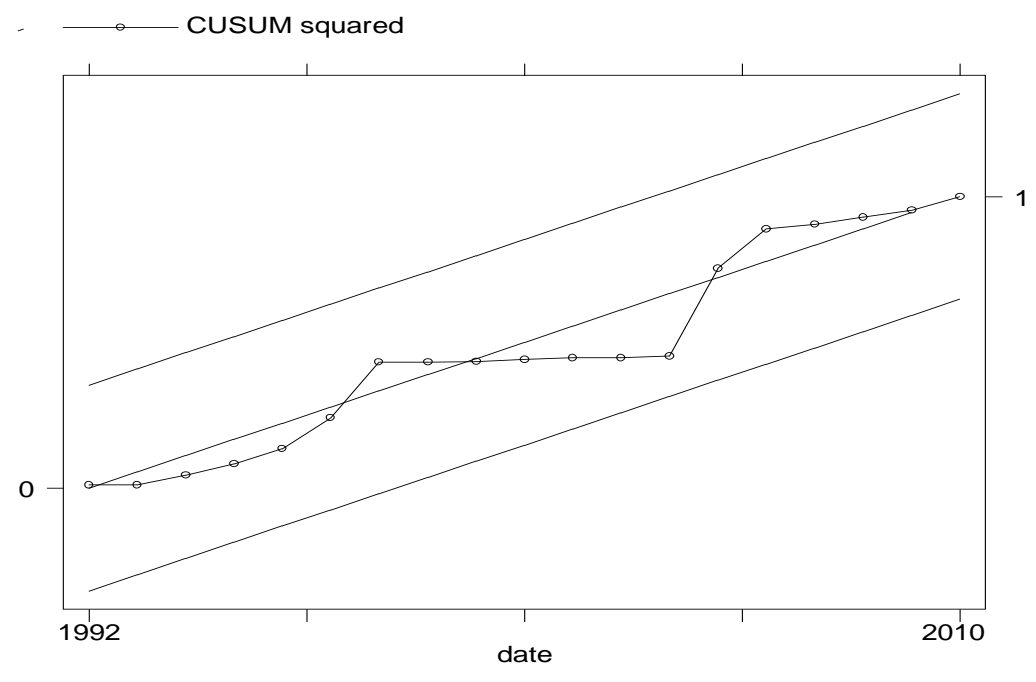

\section{Conclusion}

This study investigates the appropriate money demand specification for Turkey and its stability over the period of 1970 and 2013 by using annual data. Keynesian Liquidity Preferences relate real money balances with interest rates and national income. However, the specification of appropriate money demand equation is key to estimate the money demand elasticities. For this purpose, the three competing specifications (log-log, semi-log, and flexible specifications) for money demand are analyzed. The test results reveal that the flexible specification provides the best description of the money demand in comparison to the semi-log and log-log specification assuming unitary income elasticities. Moreover, by following the advice by Oskooee (2002), the CUSUMSQ test for stability is conducted in addition to cointegration analysis, and the results suggest that the M1 demand for money in Turkey is stable.

This result is quite crucial with two reasons. First, increasing diversity in financial instruments, financial liberalization, and technological innovations associated with electronical payments starting with 1990s have not weakened the stability of coefficients estimated from flexible specification of M1 money demand. Second, if the CBRT has tendency in the future to conduct a monetary policy based on the targeting monetary aggregates, adjusting the average growth rate of $\mathrm{M} 1$ which is consistent with price stability, given average growth rate of the economy and nominal interest rates might be a good choice. Existence of stable money demand function might give an opportunity to the CBRT to drive inflation expectations of economic agents. Moreover, a reliable relationship between $\mathrm{M} 1$ and inflation might provide monetary targeting to serve as a communications device that increases the transparency of monetary policy and CBRT accountability.

This study, being of an exploratory and interpretive nature, raises some opportunities for future research. First, the results of the study should be verified by using Divisia monetary aggregates in addition to the simple sum monetary aggregates. Moreover, stability of money demand functions with other monetary aggregates (simple sum or Divisia aggregates) can also be tested, and under the existence of some possible instabilities, the new models which capture the reasons of these instabilities (the developments in sweep technology, new regulations in financial markets, economic uncertainties, political instabilities, etc.) can be investigated in order to have stable money demands. 


\section{End Notes}

1. More details regarding the Divisia approach to monetary aggregation are provided by Barnett (1980), Barnett, Fisher, and Serletis (1992). Divisia Monetary Aggregates are available for the United Kingdom by the Bank of England, for the United States by the Federal Reserve Bank of St. Louis, and for Poland by the National Bank of Poland. Divisia monetary aggregates are provided for internal use by the European Central Bank, the Bank of Japan, and the Bank of Israel.

2. According to Hakkio and Rush (1991), since cointegration is a long-term concept, it is not reasonable to use shorter time periods and extend the number of observations with monthly and quarterly data in order to overcome the long run data inadequacy. Therefore, the advice by Hakkio and Rush (1991) has been followed, and a long-term cointegration analysis has been carried out by using an annual data set covering a quite long time period 1970-2013.

3. Phillips-Perron (1989) test is also employed in addition to the ADF test since Phillips-Perron test uses Newey-West standart errors to account for serial correlation. The test results are the same as those for the ADF test. The results are available upon request.

4. In addition to the Zivot and Andrews test, Clemente, Montanes, and Reyes (1998) test is conducted in order to include possible effects of two endogenous breaks on the series when pretesting the variables for their order of integration. Under the assumption of the two structural breaks, the results are similar to one obtained from ADF and Zivot and Andrews test.

5. There are great number of studies in money demand literature using ARDL cointegration procedure introduced by Pesaran, Shin, and Smith (2001). The ARDL procedure provides an alternative test for examining a long-run relationship irrespective of whether the regressors in the money demand equation are stationary or nonstationary. In other words, ARDL procedure does not require all variables to be I(1). However, Johansen (1991) cointegration procedure was preferred in this study since all the variables in equations (1), (2), and (3) are found to be I(1) based on the different unit root tests conducted.

\section{References}

Akaike, H. (1973). Information Theory and an Extension of the Maximum Likelihood Principle Second International Symposium on Information Theory. Budapest: Academiai Kiado.

Akinlo, A.E. (2006). The stability of money demand in Nigeria: an autoregressive distributed lag approach. Journal of Policy Modeling, 28(4), 445-452.

Algan, N., \& Gencer, S. (2011). Türkiye'de para talebi fonksiyonunun modellenmesi. Ç.Ü. Sosyal Bilimler Enstitüsü Dergisi, 20(1), 195-212.

Altıntas, H. (2008). Türkiye'de para talebinin istikrarı ve sınır testi yaklasımıyla öngörülmesi: 1985-2006. Erciyes Üniversitesi iiBF Dergisi, 30, 15-46.

Baharumshah, A.Z., Mohd, S.H., \& Masih, A.M.M. (2009). The stability of money demand in China: evidence from the ARDL Model. Economic Systems, 33(3), 231-244.

Bahmani-Oskooee, M., \& Chomsisengphet, S. (2002). Stability of M2 money demand function in industrial countries. Applied Economics, 34, 2075-2083.

Bahmani-Oskooee, M., \& Rehman, H. (2005). Stability of the money demand function in Asian developing countries. Applied Economics, 37, 773-792.

Barnett, W. A. (1980). Economic monetary aggregates: an application of aggregation and Index Number Theory. Journal of Econometrics, 14(1), 11-48.

Barnett, W. A., Fisher, D., \& Serletis, A. (1992). Consumer theory and the demand for money. Journal of Economic Literature, 30, 2086-2119.

Brown, R.L., Durbin, J., \& Evans, J.M. (1975). Techniques for testing the constancy of regression relationships over time. Journal of the Royal Statistical Society, 35, 149-192.

Cagan, P. (1956). The monetary dynamics of hyperinflation. In Studies in the Quantity Theory of Money, ed. Milton Friedman, 25-117. Chicago: University of Chicago Press.

Celik, S., \& Uzun, S. (2009). Comparison of simple sum and divisia monetary aggregates using panel data analysis. International Journal of Social Sciences and Humanity Studies,1(1),1-13 
Celik, S. (1999). Divisia monetary aggregates: an empirical investigation of their usefulness for Turkey (Unpublished doctoral Dissertation). University of Nebraska, Lincoln.

Clausen, V., \& Jeong-Ryeol, K. (2000) The long run stability of European money demand. Journal of Economic Integration, 15(3), 486-505.

Darrat, A.F., Chopin, M.C., \& Lobo, B.J. (2005). Money and macroeconomic performance: revisiting divisia money. Review of Financial Economics, 14(2), 93-101

Dickey, D. A., \& Fuller W. A. (1979). Distribution of the estimators for autoregressive time series with a unit root. Journal of the American Statistical Association, 74(366), 427-431.

Dogru, B. (2014). Türkiye'de para talebinin uzun ve kısa dönem dengesinin ARDL ve VEC yaklaşımları ile analiz edilmesi. Ekonomik ve Sosyal Araştırmalar Dergisi, 10(2), 19-31.

Friedman, M. (1956). The quantity theory of money - a restatement. In Studies in the Quantity Theory of Money, ed. M. Friedman, Chicago: University of Chicago Press.

Gencer, S., \& Arısoy, I., (2013). Türkiye'de uzun dönem geniş para (M2Y) talebinin tahmini: Zamanla değişen katsayılar yönteminden bulgular. Ege Akademik Bakış, 13(4), 515-526.

Geng, S., Jusoh, M., \& Tahir, M. (2009). The stability of money demand in China: An application of the ARDL model. ProsidingPerkem, 4(2), 98-109.

Hayo, B. (1999). Estimating a European demand for money. Scottish Journal of Political Economy, 46(3), $221-244$.

Hoffman, D.L., \& Rasche H. R. (1991). Long-run income and interest elasticities of money demand in the United States. The Review of Economics and Statistics, 73(4), 665-674.

Hoffman, D. L., Rasche, R. H., \& Tieslau, M. A. (1995). The stability of long-run money demand in five industrial countries. Journal of Monetary Economics, 35, 317-39.

Ireland, P. (2009). On the welfare cost of inflation and the recent behavior of money demand. American Economic Review, 99(3), 1040-1052.

Johansen, S. (1991). Estimation and hypothesis testing of cointegration vectors in Gaussian vector autoregressive models. Econometrica, 59 (6), 1551-1580.

Jung, A. (2016). Is Euro Area money demand for M3 still stable? The Quarterly Review of Economics and Finance, 60, 29-39.

Leong, C.M, Puah, C.H., Shazali, A.M., \& Lau, E. (2010). Testing the effectiveness of monetary policy in Malaysia using alternative monetary aggregation. The Journal of Applied Economic Research, 4(3), 321-338.

Laideler, D. (1982). Monetarist perspectives. Phillip Allan Ltd. Oxford.

Lucas, R.E. (1988). Money demand in the United States: A quantitative review. Carnegie-Rochester Conference Series on Public Policy, 29 ,137-168.

Lucas, R.E., \& Nicolini, J.P. (2015). On the stability of money demand. Journal of Monetary Economics, 73, 48-65.

Mishkin, F. S. (1998). International experiences with different monetary policy regimes (Stockholm University No. 648). Stockholm: Stockholm University.

Meltzer, A. H. (1963). The demand for money: the evidence from the time series. Journal of Political Economy, 71(3), 219-246.

Mundell, A. R. (1963). Capital mobility and stabilization policy under fixed and flexible exchange rate. Canadian Journal of Economics and Political Science, 29(4), 475-485.

Nchor, D., \& Adamec, V. (2016). Investigating the stability of money demand in Ghana. Procedia - Social and Behavioral Sciences, 220, 288-293.

Newey, W. K., \& West, K.D. (1987). A simple, positive semi-definite, heteroskedasticity and autocorrelation consistent covariance matrix. Econometrica, 55(3), 703-708.

Ozcan, B., \& Arı, A., (2013). Para talebinin belirleyenleri ve istikrarı üzerine bir uygulama: Türkiye örneği. C.B.Ü. Yönetim ve Ekonomi Dergisi, 20(2), 105-120.

Ozdemir K. A., \& Saygılı, M. (2013). Economic uncertainty and money demand stability in Turkey, Journal of Economic Studies. 40(3), $314-333$.

Pesaran, M.H., Shin, Y., \& Smith, R.J. (2001). Bounds testing approaches to the analysis of level relationships. Journal of Applied Econometrics, 16(3), 289-326.

Phillips, P. C. B., \& Perron P. (1988). Testing for a unit root in time series regression. Biometrika 75(2),335-346. 
Saatcioglu, C., \& Korap, H.L. (2005) The Turkish broad money demand. İstanbul Ticaret Üniversitesi Sosyal Bilimler Dergisi, 4(7), 139-165.

Özcan, B., \& Arı, A., (2013). Para talebinin belirleyenleri ve istikrarı üzerine bir uygulama: Türkiye örneği. C.B.Ü. Yönetim ve Ekonomi Dergisi, 20(2), 105-120.

Stock, J. H., \& Watson, M. W. (1993). A simple estimator of cointegrating vectors in higher order integrated systems. Econometrica, 61(4), 783-820.

Teles, P., \& Zhou, R. (2005). A stable money demand: looking for the right monetary aggregate. Economic Perspectives,29(1), 50-63.

TUIK (Turkish Statistical institute) (2014). Retrieved October 23, 2016, from http://www.tuik.gov.tr/Kitap.do?metod=KitapDetay\&KT_ID=0\&KITAP_ID=160.

Volker, C., \& and Jeong-Ryeol, K. (2000). The long run stability of European money demand. Journal of Economic Integration, 15(3),486-505.

Yılancı, V. (2012). Türkiye'de para talebi istikrarlılığının testi: kayan pencerelerde sınır testi yaklaşımı. Dumlupınar Üniversitesi Sosyal Bilimler Dergisi, 33, 67-74. 